\title{
Holocene climate variability in the Southern Ocean recorded in a deep-sea sediment core off South Australia
}

\author{
Matthias Moros ${ }^{\mathrm{a}, \mathrm{b}, *}$, Patrick De Deckker ${ }^{\mathrm{c}}$, Eystein Jansen ${ }^{\mathrm{a}, \mathrm{d}}$, Kerstin Perner ${ }^{\mathrm{b}}$, Richard J. Telford ${ }^{\mathrm{a}, \mathrm{e}}$ \\ ${ }^{a}$ Bjerknes Centre for Climate Research, Allégaten 55, 5007 Bergen, Norway \\ ${ }^{\mathrm{b}}$ Baltic Sea Research Institute, Seestrasse 15, 18119 Rostock, Germany \\ ${ }^{\mathrm{C}}$ Research School of Earth Sciences, The Australian National University, Canberra, ACT 0200, Australia \\ ${ }^{\mathrm{d}}$ Department of Earth Science, University of Bergen, Allégaten 41, 5007 Bergen, Norway \\ ${ }^{\mathrm{e}}$ EECRG, Department of Biology, University of Bergen, Allégaten 41, 5007 Bergen, Norway
}

\section{A R T I C L E I N F O}

\section{Article history:}

Received 23 July 2008

Received in revised form

26 March 2009

Accepted 14 April 2009

\begin{abstract}
A B S T R A C T
To understand Holocene climatic development and to determine drivers of climatic changes and climate variability, high-resolution marine proxy records are required from key oceanic locations. However, information on the Holocene climate development from the Southern Hemisphere is still rare and mainly based on terrestrial archives. Here, we present data with a high-resolution of circa 35 years from sediment cores taken east of the Great Australian Bight, where it is possible to determine Southern Ocean Holocene climate and the longer-term trends of the El Niño-Southern Oscillation (ENSO) conditions. For this purpose, we used the oxygen-isotope records of two planktonic foraminifer species Globigerinoides ruber and Globigerina bulloides which inhabit different water masses as well as faunal counts of planktonic foraminifers. After the ocean frontal systems off southern Australia were pushed northward by orbitally-forced insolation changes during the early Holocene, the data indicate increasing ENSO variability during the mid to late Holocene when the fronts shifted polewards again. A strong circa 1550 year cycle is found in the Globigerina bulloides record which reflects the wider Southern Ocean signal with prominent cold phases centred at circa 9.2, 7.3, 5.8, 4.3, 2.7, 1.4 ka BP and, possibly the Little Ice Age, which have global counterparts.
\end{abstract}

(c) 2009 Elsevier Ltd. All rights reserved.

\section{Introduction}

The study area, the Murray Canyon Group east of the Great Australian Bight (off southern Australia), lies a few degrees north of the present Subtropical Front, the northern limit of subantarctic water (Fig. 1) and is therefore a key area for studying past variability of Southern Hemisphere frontal systems in the Australian region. In addition, the area is influenced by the warm Leeuwin Current (e.g. Li et al., 1999; Middleton and Bye, 2007) whose strength seems to be linked to the El Niño-Southern Oscillation (ENSO, Pearce and Phillips, 1988).

ENSO is a key aspect of the earth's climate system and contributes a large portion of the inter-annual variability in the modern climate, with widespread economic implications (Overpeck and Cole, 2007). A number of recently-published studies focus

\footnotetext{
* Corresponding author. Baltic Sea Research Institute, Marin Geology, Seestrasse 15, 18119 Rostock, Germany. Tel.: +49 3815197 399; fax: +49 3815197350 .

E-mail addresses: matthias.moros@bjerknes.uib.no (M. Moros), patrick. dedeckker@anu.edu.au (P. De Deckker), eystein.jansen@geo.uib.no (E. Jansen), richard. telford@bjerknes.uib.no(R.J. Telford).
}

on the Holocene variability of ENSO (Gagan et al., 2004; Stott et al., 2004; Koutavas et al., 2006; Brijker et al., 2007; Donders et al., 2007), but high-resolution marine proxy records of the general climate development in the Southern Ocean sector are rare. Donders et al. (2008) summarise the recent view of Holocene ENSO development and integrate proxy data and model scenarios for the mid-Holocene onset of the modern ENSO variability. The few marine proxy data reflecting ENSO variability come mainly from the eastern Pacific Ocean and the Indo-Pacific Warm Pool area (e.g. Gagan et al., 2004; Brijker et al., 2007).

Recent progress in understanding global Holocene climatic evolution is mainly based on climate model simulations (Renssen et al., 2006; Emile-Geay et al., 2007; Seager et al., 2007). Nevertheless, climate model experiments need to be validated by proxy data sets. High-resolution marine records are available for several Northern Hemisphere sites (e.g. Giraudeau et al., 2000; Andersson et al., 2003; Risebrobakken et al., 2003; Hall et al., 2004; Moros et al., 2004), and sites under the influence of monsoonal circulation (Stott et al., 2004; Gupta et al., 2005; Brijker et al., 2007). However, except for Antarctic ice core (Masson-Delmotte et al., 2004) and terrestrial data (e.g. Haberle, 2005; Donders et al., 2007, 


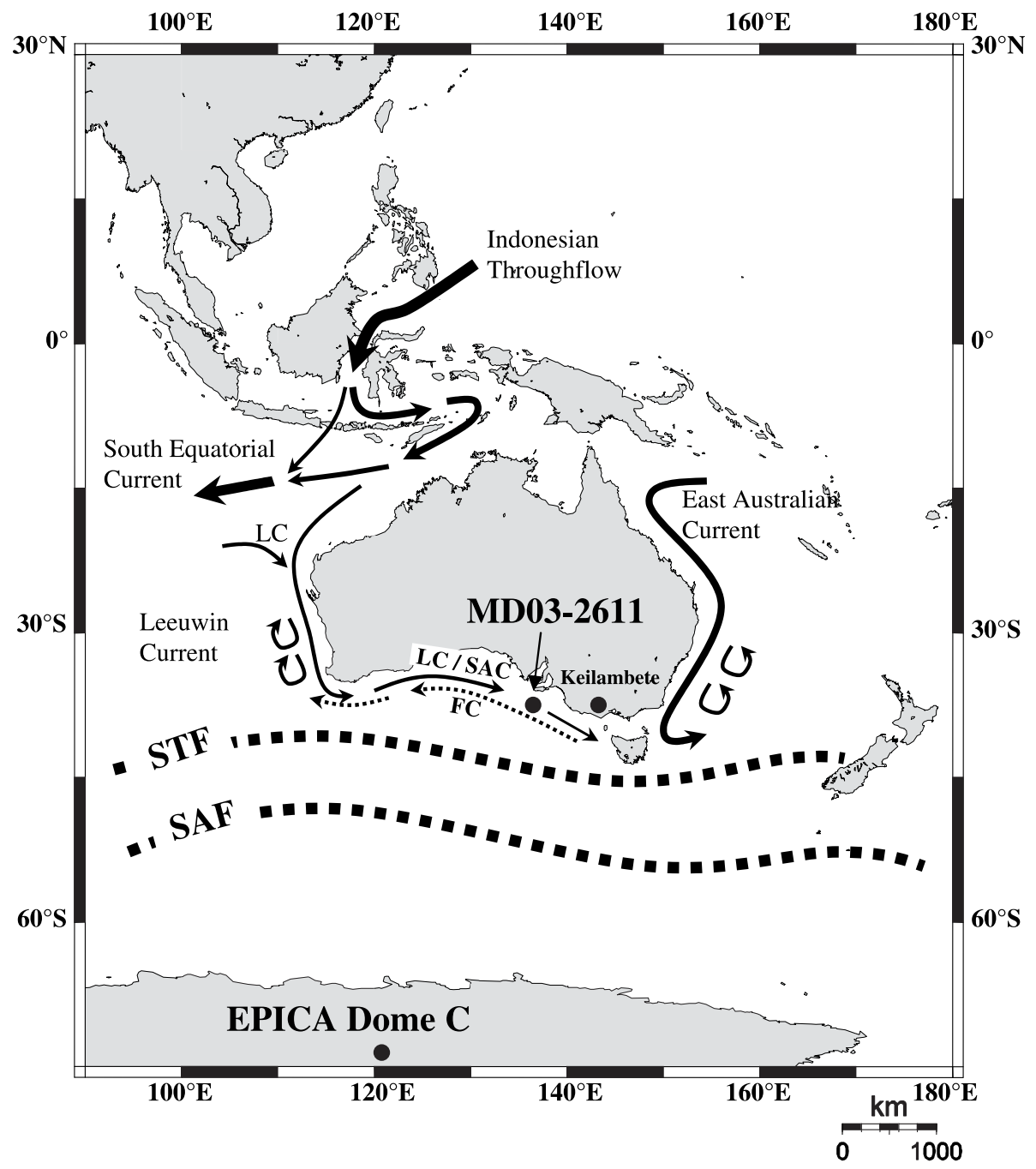

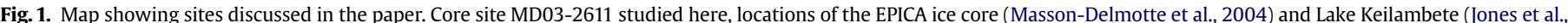

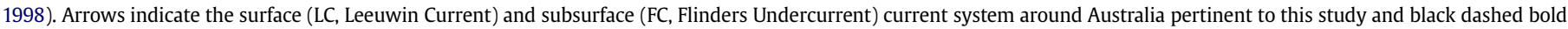
lines the recent position of frontal systems (STF, Subtropical Front; SAF, Subantarctic Front).

2008), few high-resolution marine proxy records (Nielsen et al., 2004) from the Southern Ocean sector are available to test model results.

Here, we present results on Holocene climatic development in the Southern Ocean based on a study performed in a key area (Fig. 1), the Murray Canyon Group east of the Great Australian Bight (off southern Australia).

\section{Regional setting}

A review of the shelf-slope circulation along Australia's southern shelves based mainly on instrumental data of the last 20 years is given in Middleton and Bye (2007). In the study area, at the shelfedge south of Kangaroo Island in the Murray Canyon Group, two currents determine the hydrographic conditions (Fig. 1). These are the South Australian Current (SAC) - a continuation of the warm surface Leeuwin Current (LC) - and the subsurface westward Flinders Undercurrent (FC). The modern and past long-term changes of the LC influence on the southern shelf of Australia have been subject to a number foraminiferal assemblage-based studies (Almond et al., 1993; Li et al., 1996a,b; McGowran et al., 1997; Li et al., 1999; Cann et al., 2006).
The subsurface FC, a northern boundary current along Australia's southern shelves (Middleton and Cirano, 2002), originates from Southern Ocean waters and changes in its properties track Southern Ocean dynamics. The LC (or its extension, the SAC) is a warm surface current that flows southwards along the western Australian coast, before turning eastwards and continuing towards the Great Australian Bight and sometimes further east (Fig. 1). The LC originates in the tropics, especially from Pacific Ocean water pushed westwards by the trade winds and channelled via the Indonesian Throughflow into the eastern Indian Ocean (Meyers, 1996; Feng et al., 2003; England and Huang, 2005). During winter, the warm surface LC and local winds act to drive the eastward currents and determine the properties of the SAC (Middleton and Bye, 2007). During summer, the SAC influences the study area and sea surface temperatures (SSTs) are somewhat colder than in winter (Middleton and Bye, 2007). Strong, temperature-driven water mass stratification is observed during spring and summer months. There is likely to be little variation in seawater salinity since the core site, in the vicinity of the Murray Canyons, is located away from the continental shelf.

Modern inter-annual variability in the LC, and hence the SAC, is linked to ENSO: during El Niño phases, the LC is weak; in La Niña 
phases, the current tends to flow more strongly (Feng et al., 2003). Feng et al. (2003) and Wijffels and Meyers (2004) have also shown that the strength of the LC increases by $25 \%$ (or 1 Sverdrup) between El Niño and La Niña events. The shelf-slope currents south of Australia are reduced (enhanced) during El Niño (La Niña) events and the ENSO driven currents are strongest on the shelf slope $(\mathrm{Li}$ and Clarke, 2004). Wintertime downwelling is reduced during the onset of strong El Niño events (Middleton et al., 2007). In contrast, summertime upwelling increases during La Niña events. Limited observations (Middleton et al., 2007) indicate that the mean winter time currents may be largely shut down (20-5 cm/s) during El Niño winters. However, during El Niño summers, there does not seem to be a corresponding increase in the mean currents. Middleton et al. (2007) argue that this asymmetry involves the thermohaline circulation of the reduced winter inflow of warm LC water. These authors showed that El Niño-related current variability during winter is larger than during the average annual ENSO response of $4-6 \mathrm{~cm} / \mathrm{s}$ inferred by Li and Clarke (2004) and of an order of $20 \mathrm{~cm} / \mathrm{s}$ on the shelf break. Wintertime SST anomalies are generally cooler during El Niño and warmer during La Niña events. Limited observations indicate that the thermocline $\left(11.5^{\circ} \mathrm{C}\right.$ isotherm) is raised by $170 \mathrm{~m}$ during El Niño summers (Middleton and Bye, 2007). However, there is no sound oceanographic interpretation due to the very limited instrumental data thus far available that gives information on the El Niño signal and its impact is on circulation and upwelling off South Australia (Middleton and Bye, 2007). Nevertheless, Middleton et al. (2007) clearly state that ENSO effects are important and driven by the shelf/slope wave guide and not by wind stress. We have to note that the instrumental data are limited in number and only cover the last few decades, with very few data for winter when conditions at sea are extremely difficult. The instrumental period is represented in our records by only a few data points.

\section{Material and methods}

To reconstruct Holocene changes in the surface and subsurface water conditions off South Australia, we studied planktonic foraminifera assemblage changes and obtained paired stable-oxygen isotope $\left(\delta^{18} \mathrm{O}\right)$ records of the planktonic foraminifers Globigerinoides ruber (Gs. ruber) and Globigerina bulloides ( $\mathrm{Ga}$. bulloides) from sediment cores taken south of Kangaroo Island at $36^{\circ} 43.8^{\prime} \mathrm{S}$, $136^{\circ} 32.9^{\prime} \mathrm{E}$ at a water depth of $2420 \mathrm{~m}$ by R/V Marion Dufresne in 2003 (Fig. 1). For more information on the cores see Hill and De Deckker (2004) and Gingele et al. (2007) and references therein. Piston core MD03-2611 is the main focus of this paper, but as the last 600 years of sedimentation are missing from that core, multicore (MUC05), taken at the same site, was also studied to complete the sequence.

\subsection{Chronology}

The chronology of the Holocene part (c. $2.8 \mathrm{~m}$ for the last $10 \mathrm{ka}$ ) of core MD03-2611 is based on more than 20 AMS ${ }^{14} \mathrm{C}$ dates (Fig. 2, Table 1). Sediments from a multi-core taken at same site, dated by ${ }^{210} \mathrm{~Pb},{ }^{234} \mathrm{Th}$ (by Dr S. Schmidt) and AMS ${ }^{14} \mathrm{C}$, were deposited during the last 800 years. The age/depth model was developed using a mixed-effect modelling procedure (Heegaard et al., 2005) with constant variance. This procedure uses the central 1-sigma range of the calibrated dates. AMS ${ }^{14} \mathrm{C}$ dates (see Table 1 ) were calibrated using Marine04 in OxCal4 (Bronk Ramsey, 1995, 2001). All ages referred to in this paper are calibrated kiloyears BP (ka).

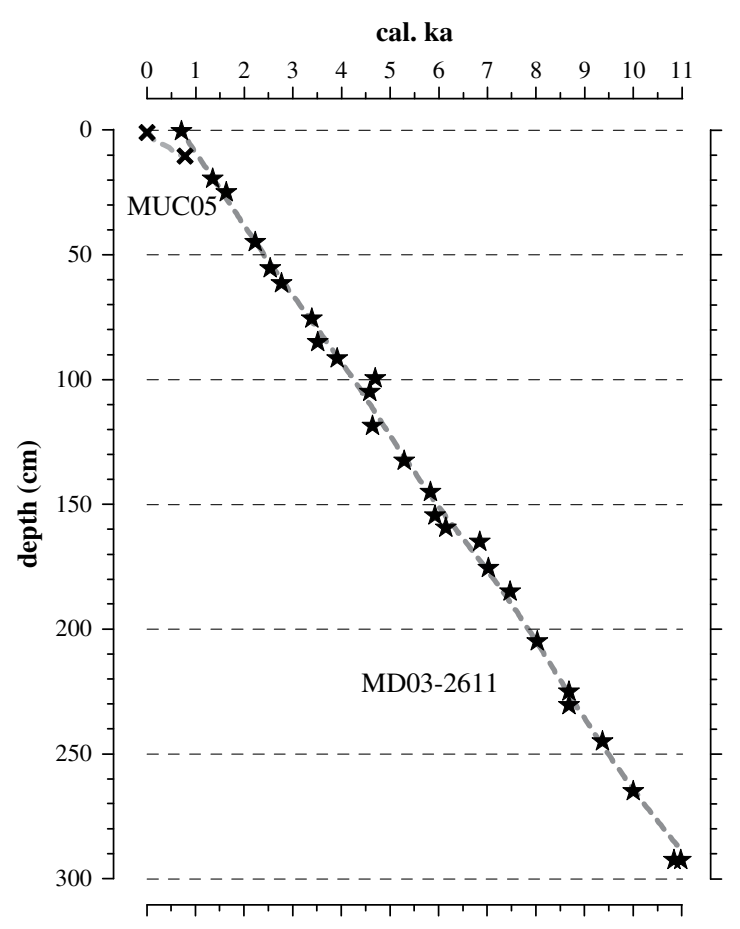

Fig. 2. The age/depth model was developed using a mixed-effect modelling procedure (Heegaard et al., 2005) with constant variance. For AMS ${ }^{14} \mathrm{C}$ dates refer to Table 1.

\subsection{Planktonic foraminifera assemblage}

The planktonic foraminifera assemblage was counted at c. $6 \mathrm{~cm}$ sampling resolution providing a mean temporal resolution of about 200-250 years. For each sample, over 400 planktonic foraminifera were identified to species level. Counts were performed on splits of the $>150 \mu \mathrm{m}$ fraction.

\subsection{Stable-oxygen isotopes}

The stable isotope analyses on Gs. ruber and Ga. bulloides were performed at the GMS laboratory of the Bjerknes Centre for Climate Research at the University of Bergen on a Finnigan MAT 251 mass spectrometer equipped with an automatic "Kiel device" preparation line. Foraminifera tests of grain size fraction $>150 \mu \mathrm{m}$ (typically 6-10 specimens) were crushed and cleaned in an ultrasonic bath before being analysed. The reproducibility of oxygen isotope measurements is $\pm 0.07 \%$ based on replicate measurements of carbonate standards. All results are reported $\delta^{18} \mathrm{O}$ in \% vs. PDB, using NBS 19 as the standard. We corrected the $\delta^{18} \mathrm{O}$ records for ice volume effects based on the results of Fairbanks (1989), where a $10 \mathrm{~m}$ sea level rise equals $0.11 \% \delta^{18} \mathrm{O}$. The sampling interval of almost $1 \mathrm{~cm}$ for Ga. bulloides and Gs. ruber in both cores provides a mean temporal resolution of about 35 years over the entire Holocene.

\subsection{Spectral analysis of oxygen isotope data}

Spectral analysis of the oxygen isotopic data was performed with REDFIT (Schulz and Mudelsee, 2002). The program works directly from unevenly spaced data, avoiding the introduction of bias during interpolation. 
Table 1

List of radiocarbon dates obtained from MD03-2611 gravity core and MUC 05 multi-corer samples.

\begin{tabular}{|c|c|c|c|c|}
\hline Depth $(\mathrm{cm})$ & Material dated & Lab. code & ${ }^{14} \mathrm{C}$ age & Calibrated age ( $1 \sigma$ range) \\
\hline \multicolumn{5}{|c|}{$\overline{M D 03-2611 \text { gravity core }}$} \\
\hline $0.5^{*}$ & Gs. ruber + Ga. bull & OZH718 & $1140 \pm 90$ & $619-786$ \\
\hline 19.5 & Gs. ruber + Ga. bull & Poz-15818 & $1820 \pm 30$ & $1313-1388$ \\
\hline $25^{*}$ & Gs. ruber + Ga. bull & OZH719 & $2060 \pm 60$ & 1549-1701 \\
\hline $45^{*}$ & Gs. ruber + Ga. bull & OZH720 & $2550 \pm 60$ & $2150-2297$ \\
\hline 55.5 & Gs. ruber + Ga. bull & Poz-15819 & $2785 \pm 35$ & 2449-2609, 2634-2641 \\
\hline 61.5 & Gs. ruber + Ga. bull & Poz-15820 & $3000 \pm 35$ & $2730-2804$ \\
\hline 75.5 & Gs. ruber + Ga. bull & Poz-18830 & $3510 \pm 40$ & $3347-3439$ \\
\hline $85^{*}$ & Gs. ruber + Ga. bull & OZH721 & $3610 \pm 90$ & $3398-3614$ \\
\hline 91.5 & Gs. ruber + Ga. bull & Poz-18831 & $3925 \pm 35$ & $3852-3959$ \\
\hline 99.5 & Gs. ruber + Ga. bull & OZJ066 & $4490 \pm 80$ & $4582-4795$ \\
\hline $105^{*}$ & Gs. ruber + Ga. bull & OZH722 & $4410 \pm 60$ & 4481-4682 \\
\hline 118.5 & Gs. ruber + Ga. bull & Poz-15821 & $4460 \pm 35$ & $4564-4713,4759-4761$ \\
\hline 132.5 & Gs. ruber + Ga. bull & Poz-15823 & $4950 \pm 40$ & 5239-5334, 5337-5351, 5374-5384 \\
\hline $145^{*}$ & Gs. ruber + Ga. bull & OZH723 & $5460 \pm 70$ & $5744-5905$ \\
\hline 154.5 & Gs. ruber + Ga. bull & Poz-15824 & $5530 \pm 40$ & $5877-5964$ \\
\hline 159.5 & Gs. ruber + Ga. bull & OZJ067 & $5740 \pm 120$ & $6007-6268$ \\
\hline $165^{*}$ & Gs. ruber + Ga. bull & OZH724 & $6370 \pm 90$ & $6727-6952$ \\
\hline 175.5 & Gs. ruber + Ga. bull & Poz-15825 & $6510 \pm 40$ & $6954-7089$ \\
\hline $185^{*}$ & Gs. ruber + Ga. bull & OZH725 & $6960 \pm 60$ & $7412-7517$ \\
\hline $205^{*}$ & Gs. ruber + Ga. bull & OZH726 & $7560 \pm 70$ & 7947-8099 \\
\hline $225^{*}$ & Gs. ruber + Ga. bull & OZH727 & $8180 \pm 90$ & $8551-8806,8819-8840$ \\
\hline 230.5 & Gs. ruber + Ga. bull & Poz-15826 & $8190 \pm 40$ & $8598-8749$ \\
\hline $245^{*}$ & Gs. ruber + Ga. bull & OZH728 & $8690 \pm 60$ & $9298-9436$ \\
\hline $265^{*}$ & Gs. ruber only & OZH729 & $9170 \pm 60$ & 9883-10104 \\
\hline 292.5 & Gs. ruber + Ga. bull & Poz-15827 & $9960 \pm 50$ & $10812-10858,10875-11065$ \\
\hline \multicolumn{5}{|c|}{ Multi-corer (MUC 05) } \\
\hline 1 & Gs. ruber + Ga. bull & Poz-18165 & $155 \pm 30$ & 0 \\
\hline 10.5 & Gs. ruber + Ga. bull & Poz-18166 & $1240 \pm 30$ & $728-821$ \\
\hline
\end{tabular}

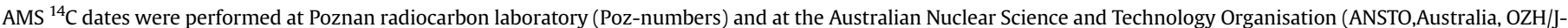

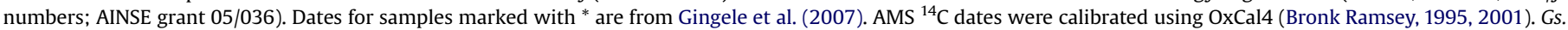
ruber stands for Globigerinoides ruber and Ga. bull for Globigerina bulloides, respectively.

\section{Results}

A total of 14 planktonic foraminifera species have been identified. The average Holocene planktonic foraminifera assemblage (Fig. 3) is dominated by Globorotalia inflata (d'Orbigny, 33\%), Globigerina bulloides (d'Orbigny, 27\%), Globigerinoides ruber white (d'Orbigny, 12\%), Neogloboquadrina pachyderma dextral (Ehrenberg, 10\%) and Globorotalia truncatulinoides (d’Orbigny, 5\%). Globigerinita glutinata (Egger, 4\%) Globoturborotalita rubescens pink (Hofker, 2\%) and Globoturborotalita tenella (Parker, 1\%), Globigerinella siphonifera (d’Orbigny, 2\%). Occasionally, Turborotalita quinqueloba (Natland), Orbulina universa (d'Orbigny), Globorotalia hirsuta (d'Orbigny)and Globigerinoides sacculifer (Brady) are found. Remarkable long-term trends are observed in the tropical to subtropical species Gt. rubescens plus Gt. tenella records which show very low abundances in the early part of the Holocene (10-7.5 ka), highest percentages in the mid Holocene (7.5-4 ka) and slightly decreasing abundances during the late Holocene. Similarly, Gr. inflata displays relatively low percentages in the early Holocene, which increase after c. $7.5 \mathrm{ka}$. The subpolar taxon Ga. bulloides shows a marked drop from over $40 \%$ before to about $25 \%$ after c. $7.5 \mathrm{ka}$. Tropical Gs. sacculifer is found with up to $1 \%$ just in the time interval 5-3 ka (not shown here). The percentage of Gs. ruber decreases over the Holocene and that of Gr. truncatulinoides increases significantly during the late Holocene from c. 4 ka to the present.

The subtropical foraminifer Gs. ruber lives in the upper $50 \mathrm{~m}$ of the water column (Bé, 1977), within the warm LC/SAC that allows Gs. ruber to grow in the otherwise relatively cold water area. Parallel $\delta^{18} \mathrm{O}$ measurements on the deeper-dwelling (50-100 m) subpolar Ga. bulloides (Bé, 1977) reflect the conditions of the Flinders Undercurrent and/or may indicate the depth of the thermocline. The $\delta^{18} \mathrm{O}$ difference between Gs. ruber and Ga. bulloides $\left(\Delta \delta^{18} \mathrm{O}_{(\text {Gs.ruber - Ga.bull })}\right)$ is a proxy for water mass stratification and/or may provide inferences about the depth of thermocline. The core-top $\Delta \delta^{18} \mathrm{O}_{(\text {Gs.ruber - Ga.bull) }}$ value of $0.7 \%$ agrees with the $3-4{ }^{\circ} \mathrm{C}$ temperature offset (at the thermocline) between LC and FC recorded in conductivity temperature depth (CTD) profiles (own data) in spring and summer. CTD profiles and SST/SSS mapping off Australia (see http://www.marine.csiro.au/remotesensing/oceancurrents) demonstrate a persistent influence of the LC/SAC through the year (references above), with a relatively stable temperature-driven water mass stratification.

During the early Holocene, the $\Delta \delta^{18} \mathrm{O}_{\text {(Gs.ruber - Ga.bull) }}$ is almost zero, but steadily increases between 9 and $6.5 \mathrm{ka}$ (Fig. 4B), with the long-term trend driven mainly by increases in $\delta^{18} \mathrm{O}$ Gs. ruber (Fig. 4B). Besides the long-term trend, the $\delta^{18} \mathrm{O}$ Gs. ruber record displays prominent maxima centred at c. 5, 3, 1.8 and $0.9 \mathrm{ka}$. In contrast to $\delta^{18} \mathrm{O}$ Gs. ruber, the $\delta^{18} \mathrm{O} G a$. bulloides record does not show long-term trends but, instead, shows pronounced millennial scale variability (amplitude of circa $0.4 \%$, or about $2{ }^{\circ} \mathrm{C}$ if interpreted as a temperature signal, see Figs. $4 \mathrm{~B}$ and $5 \mathrm{~B}$ ). These sawtooth shaped cycles, a pattern reminiscent of Dansgaard-Oeschger cycles, increase in amplitude throughout the Holocene. There is no apparent link between the $\delta^{18} \mathrm{O}$ Gs. ruber and $\delta^{18} \mathrm{O}$ Ga. bulloides records.

\section{Discussion}

Along the southern coastline of Australia, the present-day distribution of planktonic foraminifera is highly influenced by the Leeuwin Current which causes a strong longitudinal gradient from warmer water assemblages in the west to temperate assemblages in the east (e.g. Li et al., 1996b, 1999). The occurrence of Gs. ruber and Gr. inflata and the apparent lack of warm shallow water Gt. rubescens plus Gt. tenella (Bé, 1977) and tropical Gs. sacculifer in early-Holocene sediments south of Australia, demonstrate the presence 


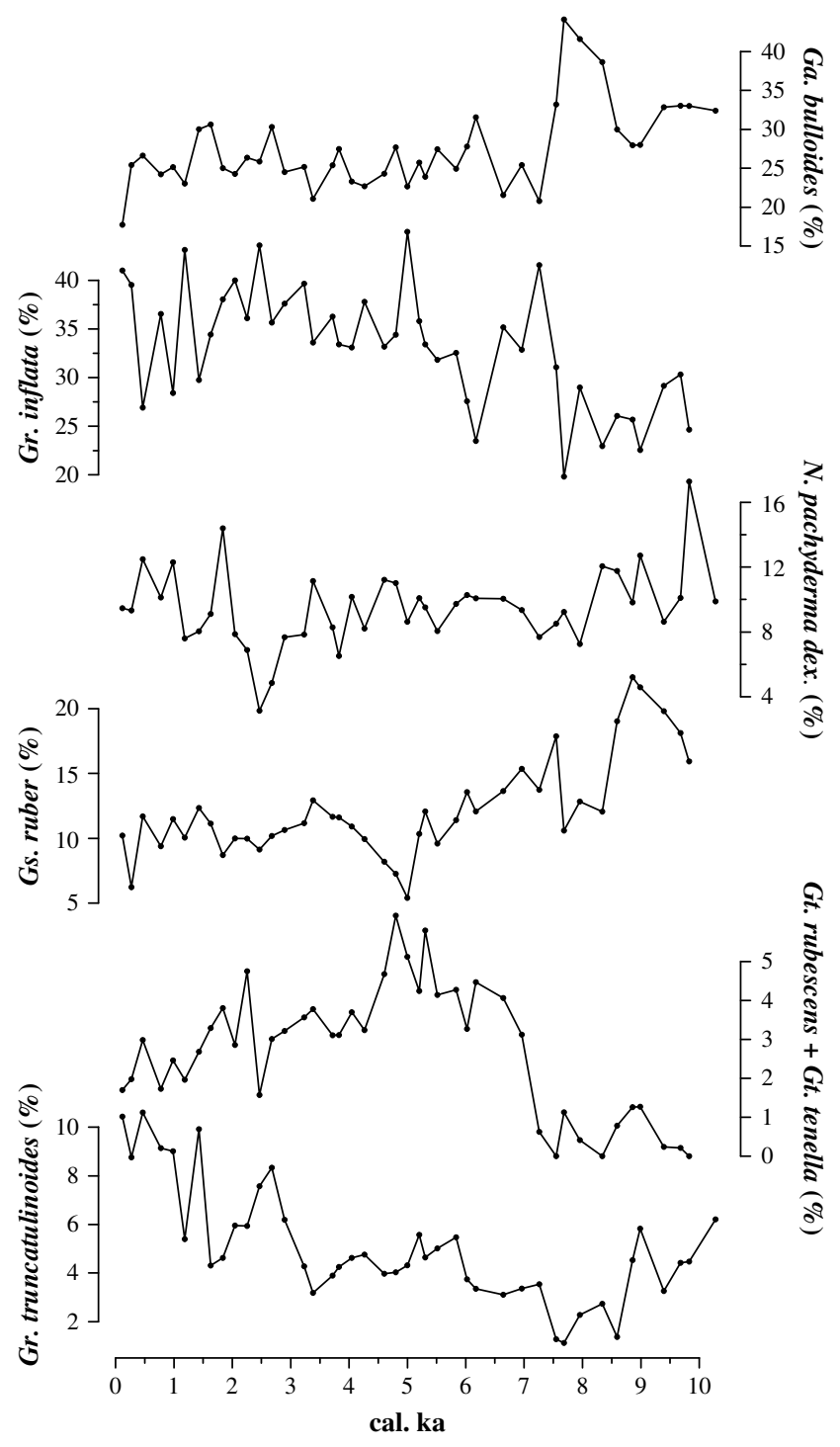

Fig. 3. Planktonic foraminifera counting data of core MD03-2611 versus age. Only species reaching $>5 \%$ are shown. Note, the low percentages of Gt. rubescens plus Gt. tenella and Gr. inflata, and the high percentages of Ga. bulloides during the early Holocene (10-7.5 ka). Abundances of Gr. truncatulinoides increase during the late Holocene.

of a weak Leeuwin Current. Almost zero $\Delta \delta^{18} \mathrm{O}_{(\text {Gs.ruber-Gabull })}$ values, relatively low percentages of Gr. inflata and Gr. truncatulinoides are indicative of weak stratification. Deep-dwelling Gr. truncatulinoides and Gr. inflata live preferentially at the base of thermocline (Bé, 1977). The ratio of Gs. ruber to Gr. inflata has been used to determine the Leeuwin Current strength along the southern coastline of Australia (Almond et al., 1993; Li et al., 1996b). However, in the study area, this ratio might not clearly reflect solely the Leeuwin Current strength. The percentage of temperate Gr. inflata (Fig. 3) which prefers a deep thermocline with little seasonal variations in salinity (Bé, 1977; Cléroux et al., 2007) parallels changes in $\Delta \delta^{18} \mathrm{O}_{\text {(Gs.ruber - Ga.bull) }}$ (Fig. $4 \mathrm{C}$ ) and in percentages of Gt. rubescens plus Gt. tenella (Fig. 4A) and of tropical Gs. sacculifer. This pattern is most likely due to changes in stratification caused by the varying strength of the LC/SAC. The low percentages of tropical and subtropical species in the early Holocene (10 to c. $7.5 \mathrm{ka}$ ) are compensated by relatively high abundances of $\mathrm{Ga}$. bulloides, which are indicative of a relatively cold water mass. The faunal and stable isotope data indicate a weak stratification of a relatively cold water mass under the Leeuwin Current influence during the early Holocene from 10 to c. $7.5 \mathrm{ka}$.

Strong westerlies in the early Holocene, caused by a steep, insolation-driven, equatorial-to-pole thermal gradient (Renssen et al., 2005; Donders et al., 2007) and a generally more northward position of the intertropical convergence zone (ITCZ; Haug et al., 2001; Koutavas et al., 2006) which resulted in a northward shift of subtropical/subantarctic fronts (Fig. 1), weakened the Leeuwin Current's influence south of Australia, and prevented water mass stratification. This interpretation is supported by lake level data (high levels in some parts of the early Holocene) from SE Australia (Jones et al., 1998) which are evidence for wetter climate conditions due to the northward shift of the fronts and stronger westerlies during the early Holocene (Fig. 4E). In addition, EPICA ice core deuterium-derived source (the subantarctic Indian Ocean) and site temperature records (Fig. 4D; Masson-Delmotte et al., 2004) indicate a protection and cooling of Antarctica by strong westerly winds and the northward shift of the subtropical/subantarctic front, respectively, which resulted in a colder source temperature of Antarctic precipitation between c. 9 and $6 \mathrm{ka}$. Moreover, speleothem data indicate a strong westerly wind influence on Tasmania during the early Holocene (Xia et al., 2001). A weakening of the westerlies near Australia due to a weaker meridional temperature gradient and a general southward movement of the ITCZ (decreasing northern and increasing southern summer insolation) pushing the fronts poleward, resulted in: (i) a generally increased Leeuwin Current influence in the study area, thus causing a clear water mass stratification with a strong thermocline (Fig. 4C); (ii) decreased precipitation in SE Australia (Fig. 4E); and (iii) almost identical source and site temperatures in the EPICA ice core during mid- to late-Holocene intervals (Fig. 4D). In our data, a warmer Leeuwin Current and stronger stratification is indicated by a marked increase in $\Delta \delta^{18} \mathrm{O}_{\text {(Gs.ruber - Ga.bull) }}$ (Fig. 4C), an increase of Gt. rubescens plus Gt. tenella (Figs. 3 and $4 \mathrm{~A}$ ) and Gr. inflata percentages (Fig. 3), a drop in Ga. bulloides abundance (Fig. 3) and the appearance of tropical Gs. sacculifer. The increase in $\Delta \delta^{18} \mathrm{O}_{\text {(Gs.- }}$ ruber-Ga.bull) is mainly driven by $\delta^{18} \mathrm{O}$ Gs. ruber changes, clearly indicating changes in surface water mass properties and stratification. Model results (Renssen et al., 2005) support this interpretation: modelled westerly wind speed is decreasing during the course of the Holocene particularly during the Austral winter months when the Leeuwin Current transport is strongest.

A general decrease in the Leeuwin Current strength and increasing ENSO variability during the late Holocene are pointed out by the increasing in amplitude of $\delta^{18} \mathrm{O}$ changes recorded in $\mathrm{Ga}$. bulloides (interpreted as a stronger upwelling of cold waters and shallowing of the thermocline). In addition, the increase in abundance of deep-dwelling Gr. truncatulinoides may hint at the stronger influence of Southern Ocean waters caused by a general shallowing of the thermocline. The observed trends fit in well with the general scenario of a stronger ENSO variability during the late Holocene found in coral and terrestrial archives, e.g. from Australia (Gagan et al., 2004; Haberle, 2005; Donders et al., 2007, 2008), and which is predicted by coupled ocean-atmosphere model results (Clement et al., 2000; Liu et al., 2000). In addition, after $6 \mathrm{ka}$, southeastern Australia became progressively arid as evidenced by the presence of aeolian clays in marine records (Gingele et al., 2007) and which is matched by an increase in windiness interpreted from the presence of aeolian quartz grains in Blue Lake in the Snowy Mountains (Stanley and De Deckker, 2002). The change detected in our core between the early and mid Holocene is further recognised by alkenone-based SST reconstructions on the same core (Calvo et al., 2007). Three prominent El Niño phases recorded in Laguna Pallcacocha on the other side of the Pacific Ocean (Moy et al., 2002) 

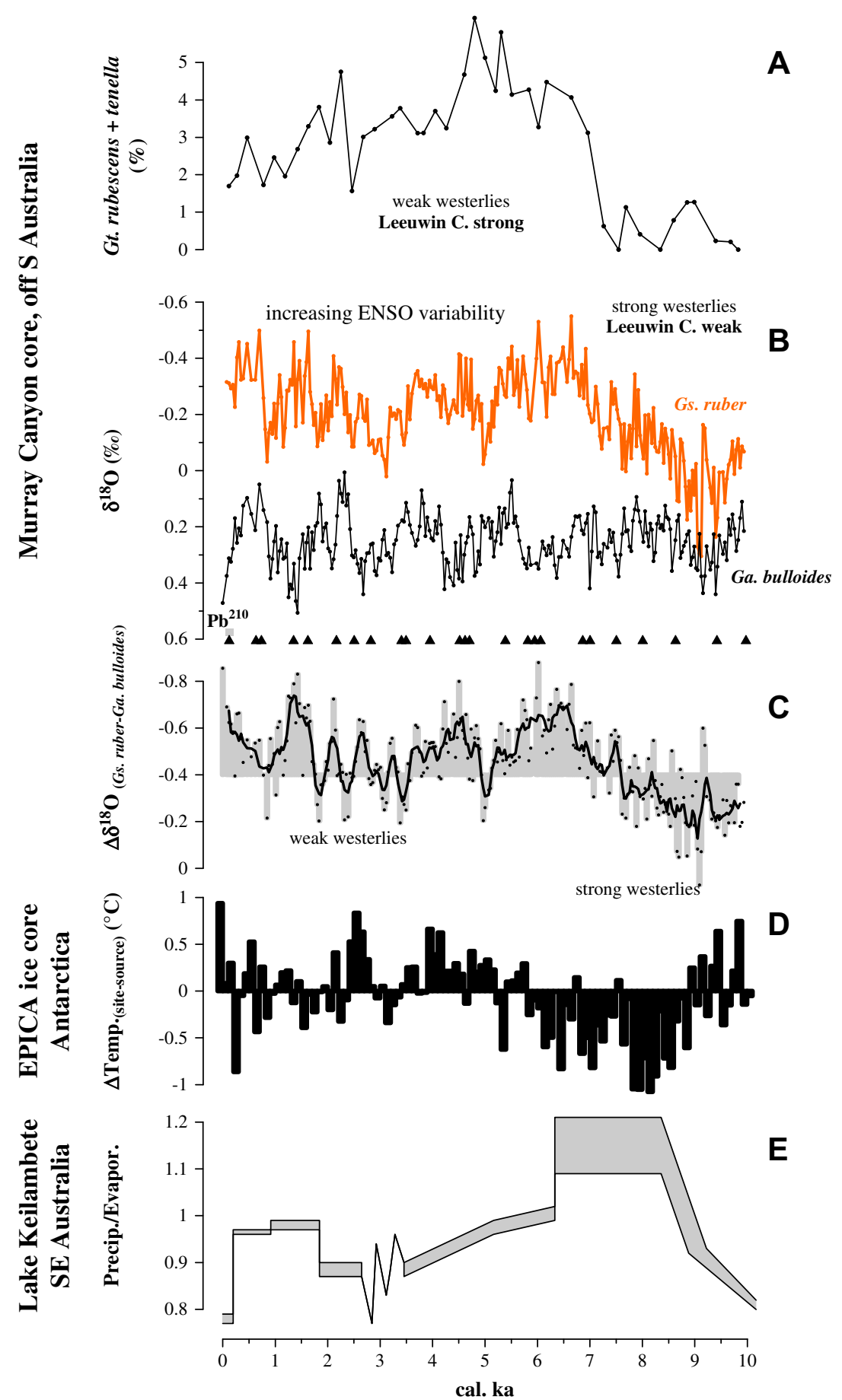

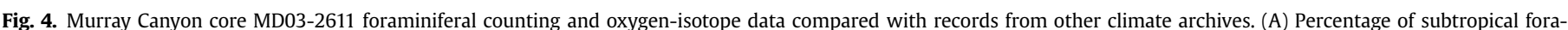

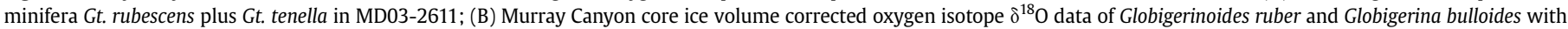

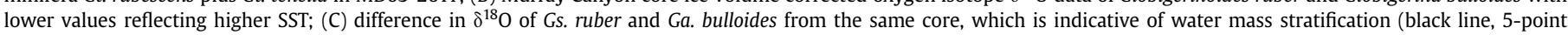

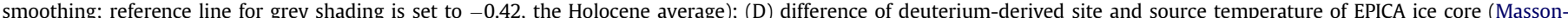

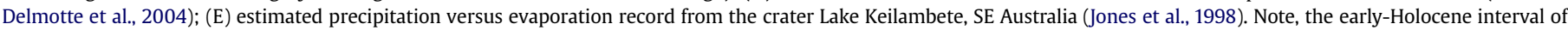

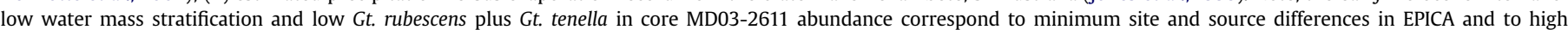

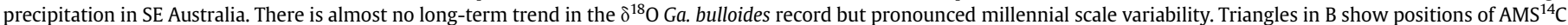
dates.

centred at 5, 3 and $0.8 \mathrm{ka}$ also seem to be evident in our data as SST lows $\left(\delta^{18} \mathrm{O}\right.$ Gs. ruber, Fig. $\left.4 \mathrm{~B}\right)$ and phases of weaker stratification $\left(\Delta \delta^{18} \mathrm{O}_{(\text {Gs.ruber - Ga.bull) }}\right.$, Fig. $\left.4 \mathrm{C}\right)$.

The apparent lack of correlation between $\delta^{18} \mathrm{O} \mathrm{Ga}$. bulloides and $\delta^{18} \mathrm{O}$ Gs. ruber and the absence of general trends in the $\delta^{18} \mathrm{O} \mathrm{Ga}$. bulloides record (apart from the change in cycle amplitude that seems to be linked to ENSO) is somewhat puzzling and cannot be explained by the available instrumental data (Middleton and Bye, 2007). The absence of a general trend is evidence of the Southern Ocean water signal in the $\delta^{18} \mathrm{O} \mathrm{Ga}$. bulloides record. Strong cold phases of the $\delta^{18} \mathrm{O} \mathrm{Ga}$. bulloides record (Fig. 5) are centred at c. 9.2, 7.3, 5.8, 4.3, 2.7, $1.4 \mathrm{ka}$, and possibly also the Little Ice Age (LIA). Most 


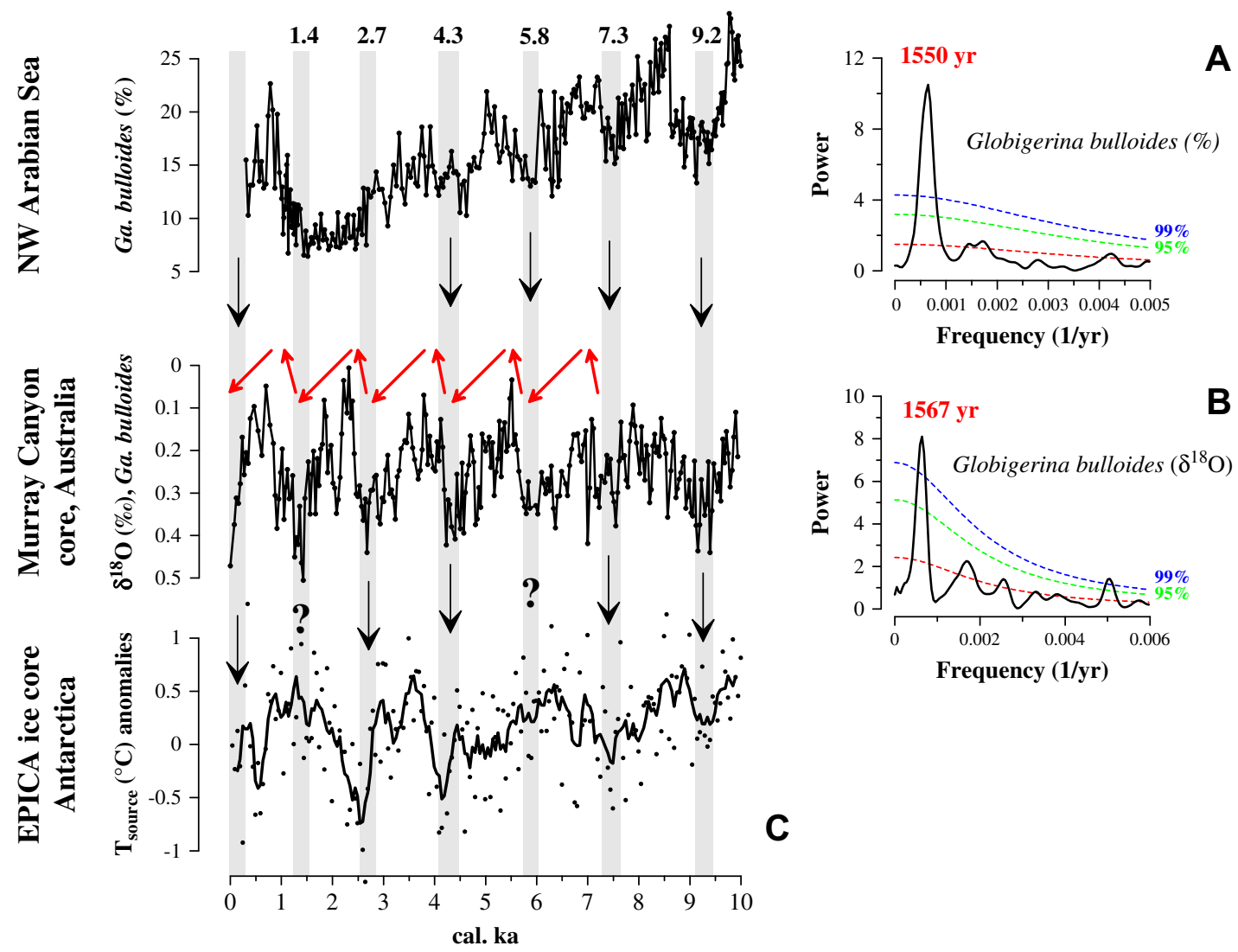

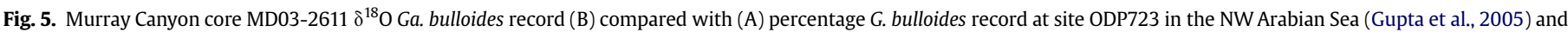

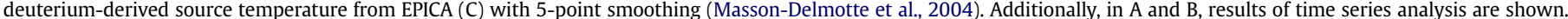

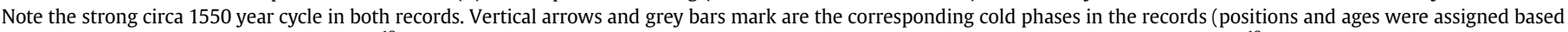

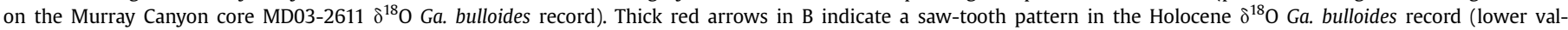
ues $=$ warmer) with slow coolings followed by rapid warmings.

of the cold phases are also evident in deuterium-derived source (subantarctic) temperatures recorded in the EPICA ice core (Fig. 5C). Particularly, the c. $4.3 \mathrm{ka}$ (Booth et al., 2005 and references therein), $2.7 \mathrm{ka}$ (e.g. Renssen et al., 2006 and references therein) and the LIA cold events are known from globally distributed sites as well as in the coral record offshore NE Australia (Hendy et al., 2002). Similar cold phases in the Northern Hemisphere are reflected by weaker upwelling (due to weak SW summer monsoon) in the NW Arabian Sea (Gupta et al., 2005; see Fig. 5A). The $\delta^{18} \mathrm{O}$ Ga. bulloides record which is indicative of Flinders Undercurrent properties, and hence of the wider Southern Ocean, seems to clearly reflect a global signal.

Whereas spectral analyses did not reveal a statistically significant periodicity in the Holocene $\delta^{18} \mathrm{O}$ Gs. ruber record, a strong 1567 year cycle appears in the $\delta^{18} \mathrm{O} \mathrm{Ga}$. bulloides record, a frequency also found in NW Arabian Sea foraminifer data (Gupta et al., 2005; Fig. 5A). Following O'Sullivan et al. (2002), we did not smooth the data prior to spectral analysis, unlike Gupta et al. (2005). Therefore, our re-analysis of the Arabian Sea data is slightly different from that of Gupta et al. (2005), especially at higher frequencies. The records are indicative of the broad cyclic patterns in the NW Indian Ocean which are driven by broad scale trade winds that would have affected the entire Indian Ocean as well as the Southern Ocean. The significance and nature of a circa 1500 year cycle during the Holocene is still under debate (e.g. Marchal, 2005; Debret et al., 2007). The inter-hemispheric character of many of the cold intervals (Fig. 5) may point to a possible coupling via the ocean circulation system. New model results (Seager et al., 2007) suggest that shifts in the poleward position of the southern westerlies may increase/decrease the Agulhas leakage which would result in more/ less transport of saltier waters into the Atlantic and finally increase/ decrease the meridional overturning circulation. This is a process that might explain the synchroneity of southern and northern climate proxy data at millennial scales.

Further proxy studies, including trace element analyses, coccolith and high-resolution planktonic and benthic foraminifera assemblage studies are needed and are underway in order to study in detail the apparently missing link between the subsurface cyclic record of $\delta^{18} \mathrm{O} \mathrm{Ga}$. bulloides and the surface $\delta^{18} \mathrm{O} \mathrm{Gs}$. ruber record.

\section{Conclusion}

Variations in the meridional thermal gradient and a generally more northern/southern position of the intertropical convergence zone (ITCZ) during the early/late Holocene triggered by orbitallyforced insolation changes explain the strength of the ENSO signal south of Australia. Thus, strong westerlies in the early Holocene, caused by a steep, insolation-driven, equatorial to pole thermal gradient and a generally more northward position of the ITCZ which resulted in a northward shift of subtropical/subantarctic fronts, weakened the Leeuwin Current influence south of Australia, and prevented water mass stratification. A weakening of the westerlies near Australia due to a weaker meridional temperature gradient and a general southward movement of the ITCZ (decreasing northern and increasing southern summer insolation) pushing the fronts poleward, resulted in an increased Leeuwin 
Current influence in the study area, causing water mass stratification with a strong thermocline.

However, the mechanisms that drive millennial scale variability with prominent cold events recorded simultaneously in Southern Ocean waters off South Australia, the NW Arabian Sea and the North Atlantic region are not clear, but our data strongly suggest the existence of such a link and should stimulate further modelling and empirical studies on this issue.

\section{Acknowledgements}

We thank John Cann and an anonymous reviewer for valuable comments that helped improve the manuscript. PDD thanks the Australian National Ocean Office for funding the cruise in March 2003, Yvon Balut and the Institut Polaire Français (IPEV) for logistical support and coring facilities, the Australian Research Council for grant DP0344932, and AINSE grant 05/36 for some of the AMS dating. The Norwegian Research Council supported the Bjerknes Centre and AMS dates and stable isotope analyses. This is publication A 230 from the Bjerknes Centre for Climate Research. Judith Shelley is thanked for sample preparation and picking some of the forams. Ulysses Ninnemann, Odd Hansen and Rune Söraas helped with stable isotope analyses, and Sabine Schmidt performed ${ }^{210} \mathrm{~Pb}$ and ${ }^{234} \mathrm{Th}$ analyses on the multi-core. Valérie Masson-Delmotte provided the EPICA ice core data and Rick Forester contributed to some discussion. We are grateful to all of them.

\section{References}

Almond, D., McGowran, B., Li, Q., 1993. Late Quaternary foraminiferal record from the Great Australian Bight and its environmental significance. Memoirs - the Association of Australasian Palaeontologists 15, 417-428.

Andersson, C., Risebrobakken, B., Jansen, E., Dahl, S.O., 2003. Late Holocene surface ocean conditions of the Norwegian Sea (Vöring Plateau). Paleoceanography 18 1044. doi:10.1029/2001PA000654.

Bé, A.W.H., 1977. An ecological, zoogeographical and taxonomic review of recent planktonic foraminifera. In: Ramsay, A.T.S. (Ed.), Oceanic Micropaleontology. Academic Press 1, London, pp. 1-100.

Booth, R.K., Jackson, S.T., Forman, S.L., Kutzbach, J.E., Bettis, E.A., Kreig, J., Wright, D.K., 2005. A severe centennial-scale drought in midcontinental North America 4200 years ago and apparent global linkages. The Holocene 15, 321-328. doi:10.1191/0959683605hl825ft.

Brijker, J.M., Jung, S.J.A., Ganssen, G.M., Bickert, T., Kroon, D., 2007. ENSO related decadal scale climate variability from the Indo-Pacific Warm Pool. Earth and Planetary Science Letters 253, 67-82.

Bronk Ramsey, C., 1995. Radiocarbon calibration and analysis of stratigraphy: the OxCal program. Radiocarbon 37, 425-430.

Bronk Ramsey, C., 2001. Development of the radiocarbon program OxCal. Radiocarbon 43, 355-363.

Calvo, E., Pelejero, C., De Deckker, P., Logan, G.A., 2007. Antarctic deglacial pattern in a $30 \mathrm{kyr}$ record of sea surface temperature offshore South Australia. Geophysical Research Letters 34. doi:10.1029/2007GL029937.

Cann, J.H., Murray-Wallace, C.V., Riggs, N.J., Belperio, A.P., 2006. Successive foraminiferal faunas and inferred palaeoenvironments associated with the postglacial (Holocene) marine transgression, Gulf St Vincent, South Australia. The Holocene 16, 224-234.

Clement, A.C., Seager, R., Cane, M.A., 2000. Suppression of El Nino during the midHolocene by changes in the Earth's orbit. Paleoceanography 15, 731-737.

Cléroux, C., Cortijo, E., Duplessy, J.C., Zahn, R., 2007. Deep-dwelling foraminifera as thermocline temperature recorders. Geochemistry, Geophysics, Geosystems 8. doi:10.1029/2006GC001474 Q04N11.

Debret, M., Bout-Roumazeilles, V., Grousset, F.E., Desmet, M., McManus, J.F., Massei, N., Sebag, D., Petit, J.-R., Copard, Y., Trentesaux, A., 2007. The origin of the 1500-year climate cycles in Holocene North Atlantic records. Climate of the Past 3, 569-575.

Donders, T.H., Haberle, S.G., Hope, G., Wagner, F., Visscher, H., 2007. Pollen evidence for the transition of the Eastern Australian climate system from the post-glacial to the present-day ENSO mode. Quaternary Science Reviews 26, 1621-1637.

Donders, T.H., Wagner-Cremer, F., Visscher, H., 2008. Integration of proxy data and model scenarios for the mid-Holocene onset of modern ENSO variability. Quaternary Science Reviews 27, 571-579.

Emile-Geay, J., Cane, M.A., Seager, R., Kaplan, A., Almasi, P., 2007. ENSO as a mediator of the solar influence on climate. Paleoceanography 22. doi:10.1029/ 2007JEG123456)

England, M.H., Huang, F., 2005. On the interannual variability of the Indonesian throughflow and its linkage with ENSO. Journal of Climate 18, 1435-1444.
Fairbanks, R.G., 1989. A 17,000-year glacio-eustatic sea level record: influence of glacial melting rates on the Younger Dryas event and deep-ocean circulation. Nature 342, 637-642.

Feng, M., Meyers, G., Pearce, A., Wijffels, S., 2003. Annual and interannual variations of the Leeuwin Current at $32^{\circ} \mathrm{S}$. Journal of Geophysical Research 108 doi:10.1029/2002JC001763.

Gagan, M.K., Hendy, E.J., Haberle, S.G., Hantoro, W.S., 2004. Post-glacial evolution of the Indo-Pacific warm pool and the El Nino-Southern Oscillation. Quaternary International 118-119, 127-143.

Gingele, F., De Deckker, P., Norman, M., 2007. Late Pleistocene and Holocene climate of SE Australia reconstructed from dust and river loads deposited offshore the River Murray Mouth. Earth and Planetary Science Letters 255, 257-272.

Giraudeau, J., Cremer, M., Manthe, S., Labeyrie, L., Bond, G., 2000. Coccolith evidence for instabilities in surface circulation south of Iceland during Holocene times. Earth and Planetary Science Letters 179, 257-268.

Gupta, A.K., Das, M., Anderson, D.M., 2005. Solar influence on the Indian summer monsoon during the Holocene. Geophysical Research Letters 32. doi:10.1029/ 2005 GL022685.

Haberle, S.G., 2005. A 23,000-yr pollen record from Lake Euramoo, wet tropics of NE Queensland, Australia. Quaternary Research 64, 343-356.

Hall, I., Bianchi, G.G., Evans, J.R., 2004. Centennial to millennial scale Holocene climate-deep water linkages in the North Atlantic. Quaternary Science Reviews 23, 1529-1536.

Haug, G.H., Hughen, K.A., Sigman, D.M., Peterson, L.C., Röhl, U., 2001. Southward migration of the intertropical convergence zone through the Holocene. Science 293, 1304-1308.

Heegaard, E., Birks, H.J.B., Telford, J.T., 2005. Relationships between calibrated ages and depth in stratigraphical sequences: an estimation procedure by mixedeffect regression. The Holocene 15, 612-618.

Hendy, E.J., Gagan, M.K., Alibert, C.A., McCulloch, M.T., Lough, J.M., Isdale, P.J., 2002. Abrupt shift in tropical sea surface salinity at end of Little Ice Age. Science 295, 1511-1514.

Hill, P.J., De Deckker, P., 2004. AUSCAN seafloor mapping and geological sampling survey on the Australian southern margin by RV Marion Dufresne in 2003. Geoscience Australia Record, 1-136. 2004/04.

Jones, R.N., Bowler, J.M., McMahon, T.A., 1998. A high resolution Holocene record of $\mathrm{P} / \mathrm{E}$ ratio from closed lakes in Western Victoria. Palaeoclimates 3, 51-82.

Koutavas, A., deMenocal, P., Olive, G.C., Lynch-Stieglitz, J., 2006. Mid-Holocene El Nino-Southern Oscillation (ENSO) attenuation revealed by individual foraminifera in eastern tropical Pacific sediments. Geology 34, 993-996.

Li, J., Clarke, A.J., 2004. Coastline direction, inter-annual flow and the strong El Nino currents along Australia's nearly zonal southern coast. Journal of Physical Oceanography 34, 2373-2381.

Li, Q., James, N.P., Bone, Y., McGowran, B., 1996a. Foraminiferal biostratigraphy and depositional environments of the mid-Cenozoic Abrakurrie Limestone, Eucla Basin, southern Australia. Australian Journal of Earth Sciences 43, 437-450.

Li, Q., James, N.P., Bone, Y., McGowran, B., 1999. Palaeoceanographic significance of recent foraminiferal biofacies on the southern shelf of Western Australia: a preliminary study. Palaeogeography, Palaeoclimatology, Palaeoecology 147, 101-120.

Li, Q., McGowran, B., James, N.P., Bone, Y., 1996b. Foraminiferal biofacies on the midlatitude Lincoln Shelf, South Australia: oceanographic and sedimentological implications. Marine Geology 129, 285-312.

Liu, Z., Kutzbach, J., Wu, L., 2000. Modelling climate shift of El Niño variability in the Holocene. Geophysical Research Letters 27, 2265-2268.

Marchal, O., 2005. Optimal estimation of atmospheric ${ }^{14} \mathrm{C}$ production over the Holocene: paleoclimate implication. Climate Dynamics 24, 71-88.

Masson-Delmotte, V., Stenni, B., Jouzel, J., 2004. Common millennial-scale variability of Antarctic and Southern Ocean temperatures during the past 5000 years reconstructed from the EPICA Dome C ice core. The Holocene 14, 145-151.

McGowran, B., Li, O., Cann, J., Padley, D., McKirdy, D.M., Shafik, S., 1997. Biogeographic impact of the Leeuwin Current in southern Australia since the late middle Eocene. Palaeogeography, Palaeoclimatology. Palaeoecology 136, 19-40.

Meyers, G., 1996. Variation of Indonesian throughflow and the El Nino-Southern Oscillation. Journal of Geophysical Research 101 (12), 255-12,263.

Middleton, J.F., Arthur, C., Van Ruth, P.D., Ward, T.M., McClean, J.L., Maltrud, M.E., Gill, P., Levings, A., Middleton, S., 2007. El Niño effects and upwelling off South Australia. Journal of Physical Oceanography 37, 2458-2477.

Middleton, J.F., Bye, J.A.T., 2007. A review of the shelf-slope circulation along Australia's southern shelves: Cape Leeuwin to Portland. Progress in Oceanography 75, 1-41.

Middleton, J.F., Cirano, M., 2002. A northern boundary current along Australia's southern shelves: the Flinders Current. Journal of Geophysical Research 107. doi:10.1029/2001JC000701.

Moros, M., Emeis, K.C., Risebrobakken, B., Snowball, I., Kuijpers, A., McManus, J., Jansen, E., 2004. Sea surface temperatures and ice rafting in the Holocene North Atlantic: climate influences on northern Europe and Greenland. Quaternary Science Reviews 23, 2113-2126.

Moy, C.M., Seltzer, G.O., Rodbell, D.T., Anderson, D.M., 2002. Variability of El Niño/ Southern Oscillation activity at millennial timescales during the Holocene epoch. Nature 420, 162-165.

Nielsen, S.H.H., Koc, N., Crosta, X., 2004. Holocene climate in the Atlantic sector of the Southern Ocean: controlled by insolation or oceanic circulation? Geology $32,317-320$ 
O'Sullivan, P.E., Moyeed, R., Cooper, M.C., Nicholson, M.J., 2002. Comparison between instrumental, observational and high resolution proxy sedimentary records of Late Holocene climatic change - a discussion of possibilities. Quaternary International 88, 27-44.

Overpeck, J.T., Cole, J.E., 2007. Lessons from a distant monsoon. Nature 445, 270-271.

Pearce, A.F., Phillips, B.F., 1988. ENSO events, the Leeuwin Current and larval recruitment of the Western Rock Lobster. Journal du Conseil International pour l'Exploration de la Mer 45, 13-21.

Renssen, H., Goosse, H., Fichefet, T., Masson-Delmotte, V., Koc, N., 2005. Holocene climate evolution in the high-latitude Southern Hemisphere simulated by a coupled atmosphere-sea ice-ocean-vegetation model. The Holocene 15, 951-964.

Renssen, H., Goosse, H., Muscheler, R., 2006. Coupled climate model simulation of Holocene cooling events: oceanic feedback amplifies solar forcing. Climate of the Past 2, 79-90.

Risebrobakken, B., Jansen, E., Andersson, C., Mjelde, E., Hevroy, K., 2003. A highresolution study of Holocene paleoclimatic and paleoceanographic changes in the Nordic Seas. Paleoceanography 18, 1017-1031.
Schulz, M., Mudelsee, M., 2002. REDFIT: estimating red-noise spectra directly from unevenly spaced paleoclimatic time series. Computers and Geosciences 28 421-426.

Seager, R., Graham, N., Herwejer, C., Gordon, A.L., Kushnir, Y., Cook, E., 2007. Blueprints for Medieval hydroclimate. Quaternary Science Reviews 26 , 2322-2336.

Stanley, S., De Deckker, P., 2002. A Holocene record of allochthonous, aeolian minera grains in an Australian alpine lake; implications for the history of climate change in southeastern Australia. Journal of Paleolimnology 27, 207-219.

Stott, L., Cannariato, K., Thunell, R., Haug, G.H., Koutavas, A., Lund, S., 2004. Decline of surface temperature and salinity in the western tropical Pacific Ocean in the Holocene epoch. Nature 431, 56-59.

Wijffels, S., Meyers, G., 2004. An intersection of oceanic waveguides: variability in the Indonesian throughflow region. Journal of Physical Oceanography 34, 1232-1253.

Xia, Q., Zhao, J.-X., Collerson, K.D., 2001. Early-Mid Holocene climatic variations in Tasmania, Australia: multi-proxy records in a stalagmite from Lynds Cave. Earth and Planetary Science Letters 194, 177-187. 